ARTICOLE

\title{
ASPECTE PRIVIND EVOLUȚIA ȘI APLICABILITATEA BUNEI-CREDINȚE ÎN DREPTUL ROMAN
}

Cristina Pop*

Rezumat: La Roma, arealul relației omului cu divinitatea a fost matca în care a apărut și s-a dezvoltat conceptul de obligație mutuală, fides. Pe de o parte, aceasta presupunea respectarea cu scrupulozitate a religiei strămoşești, îndeplinirea întocmai a promisiunilor făcute divinității, iar pe de alta, fides reprezinta și o trăsătură de ordin moral a celui în cauză. A fi de bună-credință înseamna a da dovadă de loialitate, sinceritate, onestitate; a-ți respecta cuvântul dat, a-ți ține promisiunea făcută. Ulterior, termenul în cauză a fost transformat într-un concept juridic, devenind ceea ce cunoaștem astăzi ca bona fides. Utilizat inițial în epoca republicană, întâlnim conceptul de bună-credință în cele mai vechi surse de drept civil clasic, ca Edictul Perpetuu și Instituțiile lui Gaius, și o găsim aplicată inclusiv în dreptul imperial, dovadă fiind Corpus Iuris. Va fi studiat în facultățile erei medievale şi va primi un loc de cinste în dreptul civil occidental. Probitatea, diligența, liceitatea și abținerea de la păgubirea altuia (alterum non laedere), ca elemente componente ale bona fides, au tradus, în plan juridic, acel honeste et recte vivere preluat de la stoici şi s-a perpetuat în contemporaneitate ca principiu de drept indispensabil raporturilor contractuale.

* Cristina Pop, asistent universitar doctor, Universitatea Babeș-Bolyai din Cluj, cristina.pop@law.ubbcluj.ro. 
Cuvinte cheie: fides, bona fides, acțiuni de bună-credință, oportere ex fide bona, exceptio doli, pretor, formula de judecată, echitate.

\author{
ASPECTS REGARDING THE EVOLUTION \\ AND APPLICABILITY OF BONA FIDES IN \\ ROMAN LAW
}

\begin{abstract}
In Rome, the area of the human relationship with the deity was the framework in which appeared and developed the concept of mutual obligation, fides. On the one hand, this meant carefully observing the ancestral religion and fulfilling the promises made to the deity; on the other hand, fides was also a moral trait of the person in question. To be of good faith means to show loyalty, sincerity, honesty; to obey your word, to keep your promise. Subsequently, the term in question was transformed into a legal concept, becoming bona fides. Initially used in the Republican era, we find the concept of good faith in the oldest sources of classical civil law, such as the Perpetual Edict and the Institutions of Gaius and we find it applied even in imperial law, proof being Corpus iuris. It will be studied in the faculties of the medieval era and will receive a place of honour in Western civil law. Probability, diligence, lawlessness and abstention from the harm of another (alterum non laedere), as component elements of bona fides, have translated, in the legal plane, that honest and direct life taken from the Stoics and has been perpetuated in contemporaneity as an indispensable principle of law.

Keywords: fides, bona fides, good-faith actions, oportere ex fide bona, exceptio doli, prætor, the formula procedure, equity.
\end{abstract}

\title{
1 INTRODUCERE
}

Buna-credință este un concept complex. Își are originea în unele fapte psihologice, se circumscrie în cadrul normelor morale și acționează în 
relațiile sociale, constituie mobilul raporturilor juridice și produce efecte în variate instituții de drept ${ }^{1}$.

Viața socială în lumea antică, nu doar în cea romană, a gravitat în jurul relațiilor de prietenie, de încredere între membri acesteia². La Roma, un bun exemplu îl reprezintă raportul dintre patron şi clientul său: în schimbul protecției patronului, clientul îi datora acestuia loialitate plus unele servicii de natură materială3. Încercând să caracterizăm printr-un singur termen aceste fundamente etico-sociale, fides este cel mai potrivit, cu nuanțele pe care le implică: cel de încredere și cel de credință4.

\section{FIDES ȘI RELIGIA ROMANĂ}

Totuşi, ce semnifică fides, cum îl încadrăm temporal și în ce mod a evoluat în cadrul societății romane, ținând seama că părerile romaniștilor sunt împărțite în ceea ce privește originea sa religioasă sau etică/morală5?

Pentru a afla răspunsul la această întrebare este necesar ca inițial să parcurgem un itinerar în viaţa religioasă a romanilor. La Roma, cultul zeilor era unanim considerat o însușire firească a omului, în calitatea sa de membru al comunității politice. Cu privire la această chestiune au existat două opinii. Prima aparține lui Cicero, de la care aflăm că în societatea romană nu îi era

\footnotetext{
${ }^{1}$ L. Josserand, Les mobiles dans les actes juridiques de droit prive, Paris, 1928, p. 209 apud D. GHERASIM, Buna-credință în raporturile juridice civile, Ed. Academiei Republicii Socialiste România, București, 1981, p. 8.

2 C. C. Turpin, Bonae Fidei Iudicia, Cambridge L. J. , 1965, p. 262.

3 D.H. van ZYL, Equity in Roman Law and Legal Thought, 24 De Jure 94, 1991, p.102.

4 D. NORR, Reflections on faith, friendship, mandate, 25 Irish Jurist (N. S.), p. 302.

5 L. WAELKENS, Reflexions sur la bona fides et la mala fides dans la tradition du droit ronain, The Legal History Review, nr. 86, 2018, p. 3-4.
} 
îngăduit nimănui să aibă zeii proprii, nici să se roage unor zei noi sau străini, acceptate fiind doar divinitățile recunoscute oficial ${ }^{6}$. Prin această afirmație Cicero nu face decât să evidențieze caracterul deist și conservator al religiei vechilor romani. Mai mult, același filozof roman pune pe seama puterii divinităţilor formarea şi ascensiunea Imperiului datorită faptului că ele guvernează toate popoarele și toate națiunile7. Per a contrario alți istorici susţin flexibilitatea cultului religios roman, în sensul că „nu este impusă nicio credință religioasă... respectul datorat zeilor cărora cetatea a hotărât să se închine se mărginește la un singur lucru: respectarea zilelor de sărbătoare"8.

Religia romană se învedera a fi contractualistă, aceasta deoarece în relațiile cu zeii romanii aplicau principiul do ut des ${ }^{9}$. Din acest motiv istoricul Eugen Cizek afirmă că „romanii se dovedeau a fi în acelaşi timp un popor religios şi non-religios. Orice act uman implica o latură sacră... se privilegia un contract între om și zeitate, care prescria autonomia acestor două entități, fiecare acționând de sine stătător şi omologând contactul dintre ele numai în cadrul acestui contract. Dacă zeul nu acorda omului ceea ce el îi solicita, dacă aşadar el nu își respecta contractul, omul îl părăsea și se adresa altei zeități."1o Prin urmare, ajutorul divinităților se baza, în fond, pe acţiunea decisivă a muritorilor.

6 Cicero, De Legibus, 2.8.19.

7 Amintim aici că în concepția filozofică a romanilor lumea era un ansamblu sau un sistem de forțe aflate în echilibru și totodată codependente, în sensul că acțiunile umane erau cele care mențineau sau tulburau pacea dintre oameni și zei.

${ }^{8}$ P. ARIES, G. DubY, Istoria vieții private, Vol. I, Ed. Meridiane, București, 1994, p. 166.

9 Contract nenumit în care îți dau un lucru pentru a-mi da altul (schimbul). Pentru detalii a se vedea M.D. Вов, Manual elementar de drept privat roman, Ed. Universul Juridic, București, 2016, p. 262.

${ }^{10}$ E. CIZEK, Istoria Romei, Ed. Paideia, București, 2002, p. 16. 
Ce reprezenta pentru romani un zeu? O explicație interesantă o găsim în Istoria vieții private, unde autorii susțin că zeii își trăiesc viața ca oamenii, iar existența lor nu se mărginește la un rol metafizic, fiind astfel unul dintre cele trei neamuri care populează lumea: animalele, oamenii și zeiii ${ }^{11}$. Romanii, de exemplu, râdeau de zeii cu trup de animal la care se închinau egiptenii deoarece zeii romanilor se află deasupra oamenilor, fiind raționali (asemeni ființelor umane) și nemuritori (trăsătură specifică divinității). Chiar dacă, de cele mai multe ori, folosirea termenului de zeu se referea la o singură divinitate $^{12}$, individualizată, romanii invocau la fel de des „zeii” laolaltă. În locul pluralului ei foloseau singularul, vorbeau de cele divine la neutru sau de „zeu” în general (aşa cum filosofia folosește termenul de „om”, spre exemplu). Cât privește relația om-divinitate sau raportarea celui dintâi la zeități, găsim în Cicero cea mai scurtă și cuprinzătoare definiție a religiei în lumea romană: religione, id est cultu deorum ${ }^{13}$.

În acest areal, care privește relația omului cu divinitatea, apare și conceptul de obligație mutuală, fides. Pe de o parte aceasta presupunea respectarea cu scrupulozitate a religiei strămoșești, a loialității față de prieteni și față de cetate, iar pe de alta, îndeplinirea întocmai a promisiunilor făcute divinităţiii ${ }^{14}$.

\footnotetext{
${ }^{11}$ P. ARIES, G. DUBY, op.cit., p. 212.

${ }^{12}$ Izvoarele istorice permit aprecierea existenței a trei grupe mari de zei în Statul Roman: Di Indigestes - zeii autohtoni, Di Nouensiles - zeii noi, importați de la peregrini și acceptați de către stat, Di Consentes - un grup de 12 divinităţi, 6 masculine și 6 feminine.

13 CiCERo, De natura deorum, 2.8.

14 Un sinonim imperfect pentru fides, în vremurile timpurii, ar putea fi şi pietas. Vezi şi E. CIZEK, op.cit., p. 17.
} 
„Fides enim nomen ipsum mihi videtur habere, cum fit quod dicitur; dictorum conventorumque constantia et veritas; bona fides exigit, ut quod convenit fiat." ${ }^{5}$

Anumiți termeni latini, care doar târziu au fost utilizați în domeniul juridic, au avut la începuturi uzanță religioasă. Acelaşi parcurs îl întâlnim și în cazul termenului fides, căruia în vechiul drept roman nu i se dădea semnificația pe care o presupune în următoarele secole de dezvoltare a dreptului. Tocmai din acest motiv este necesar să se distingă între perioada veche şi celelalte perioade în care conceptul de fides primește în cele din urmă un caracter laic ${ }^{16}$.

Titus Livius în $A b$ Urbe condita detaliază cum, în epocile arhaice, romanii „obişnuiau să însoțească încheierea contractelor cu unele proceduri sacrificiale; chiar şi tratatele suportau acelaşi ritual sacrificial; de obicei, îi aduceau lui Jupiter un porc drept jertfă, pentru a simboliza garanția bunei lor credințe (şi asta datorită faptului că, în simbolistica prerogativelor divine, Deus Fidius - zeul tutelar al jurămintelor nu era altul decât Zeul Suprem Juppiter Optimus Maximus sau Juppiter Capitolinus) şi o chezăşie a răscumpărării divine a păcatului de încălcare a învoielilor; ca atare, în caz de dezicere de obligația convențională asumată, aşa cum ei au lovit porcul sacrificat, Jupiter și-ar fi îndreptat împotrivă-le retorsiunea” ${ }^{17}$, dar cu „o forță pe atât mai mare pe cât era porcul de puternic"18. Aceasta se întâmpla în

15 CicERO, De Oficiis, 1.7.23; De Re Publica 4.7.21.

${ }^{16}$ L. LOMBARDI, Dalla Fides alla Bona fides, Milan,1961, p.57 și urm. apud R.M. RAMPELBERG, Du religieux au laic dans le droit romain ancient, în Le droit entre laicisation et neosacralisation, Presses Universitaires de France, 1997, p. 49.

17 V.M. CIUCĂ, Lecții de drept roman, vol. III, Ed. Polirom, Iași, 2000, p. 796.

18 J. Chevalier, Alain GHEERbrant, Dicţionar de simboluri, vol. III, p. 88 apud V.M. CiuCĂ, Bona fides într-o nouă hermeneutică, 2015, https://juridice.ro/essentials/246/bona-fidesintr-o-noua-hermeneutica. 
raporturile private, contractuale, convenționale, în pacte și fidejusiuni. Să nu omitem însă că și domeniul vieții publice a fost marcat de un veritabil cult al bunei-credințe, după cum același Titus Livius consemnează: regele Numa ,a inițiat un sacrificiu anual pentru Fides și, în această împrejurare, flaminii majori, purtați cu toții de același car, acționau împreună, împlinind gesturile rituale cu mâna dreaptă complet înfășurată."19 În esență, Juppiter Capitolinus este un chezaş al bunei-credințe, adică al jocului acceptat al credinței în aparența invocată. Această aparență invocată și acceptată prin credință este, de fapt, chintesența definițională a oricărui tratat, a oricărei convenții, a oricărui contract, ca însemn suprem al certitudinii. George Dumézil face o similară interpretare a poziției jupiteriene în spectrul buneicredințe cultice romane; o bună-credință ridicată la rang de divinitate (Fides) de către urmaşul lui Romulus Quirinus, nimeni altul decât regele Numa Pompilius $^{20}$. Iată ce consemnează, în sus-menționatul sens, Dionysios din Halicarnas, inspirat de Varro: „Nu există simțământ mai înalt și mai sfânt decât buna-credință în treburile de stat și în relațiile dintre oameni; încredințat de acest adevăr, Numa, cel dintâi dintre oameni, a întemeiat un templu pentru Fides Publica (buna-credință obștească) și, în cinstea ei, sacrificii tot atât de oficiale ca și cele ale celorlalți zei.” ${ }^{21}$ De asemenea, în opera lui Plutarh, este menționat faptul că regele Numa „cel dintâi, a clădit un templu pentru Fides şi că i-a învățat pe romani cel mai sfânt jurământ al lor, cel în numele ei.”22

\footnotetext{
19 G. DumÉzIL, Mit și epopee, vol. I, traducere de Francesca Băltăceanu, Gabriela Creția, Dan Slușanschi, Ed. Științifică, București, 1993, p. 194 apud V.M. Ciucă, op.cit.

20 V.M. CIUCĂ, op.cit.

${ }^{21}$ G. DUMÉZIL, op.cit., p. 194 apud V.M. CIUCĂ, op.cit.

22 Ibidem.
} 
Observăm cum diversitatea tradițiilor ne obligă să punem la baza unui fapt cert un personaj legendar. Deși perceput ca zeiță, conceptul de Fides a evoluat și s-a modificat în conținutul său în conformitate cu înțelesul semantic profund pe care îl avea.

O caracteristică importantă a istoriei lui Fides (aceasta nefiind bona fides) a fost una morală, după cum precizează Plaut la finele Republicii. În viziunea acestuia termenul de fides se află în corespondență cu fit quod dicitur, fiind o morală care implica întreaga societate și care, în timp, va deveni individuală. Conform Dictionnaire de la culture juridique, fides reprezintă şi o trăsătură de ordin moral a celui în cauză. A fi de bună-credință înseamnă a da dovadă de loialitate, sinceritate, onestitate; a-ți respecta cuvântul dat, a-ți ține promisiunea făcută²3. Sub influența greacă, ideea promovată de ceea ce reprezenta zeița Fides ajunge să fie secularizată, mărginindu-se doar la un caracter stric etic al acesteia.

\section{DE LA FIDES LA BONA FIDES}

Lăsând la o parte semnificația religioasă și etică, un pas fundamental în crearea principiului bunei-credințe s-a realizat în momentul în care fides a fost transformat într-un concept juridic ${ }^{24}$. Astfel, dreptul roman a separat noțiunea juridică de bună-credință de noțiunea onestității (honestum)25. Dacă sub aspect lingvistic au rezultat derivatele fidus (sigur, de încredere), fidelis (credincios), fiducia (încredere, siguranță), confidere (încredere),

23 D. Alland, S. Rials (dir.), Dictionnaire de la culture juridique, Presses Universitaires de France, Lamy-Puf, 2003, p. 143.

24 D. NORR, op.cit., p. 302

25 D. GHERASIM, op.cit., p. 8. 
conceptul de fides, ca jurământ sau promisiune, implică în vechiul drept roman, supunere; exemple sunt fiducia, fideicommisium, fideipromissio și fideiussio ${ }^{26}$, instituții stricti iuris. Mergând mai departe și calificând fides ca bona, o plasăm pe aceasta în fruntea listei de valori etice ${ }^{27}$. Începând cu sec. II î.Hr. se vorbește despre termenul de bona fides. Astfel, arhaicul fides va reveni sub un alt înțeles și sub o altă formă, cea de bona fides, în raporturile contractuale ale lui ius gentium $^{28}$. În acest mod s-au favorizat relațiile dintre cetățenii romani și străini, independent de existența vreunui tratat între vechile popoare $^{29}$. În istoria dreptului, diferența făcută de romani între contractele de bună-credință și cele de drept strict poate fi catalogată ca punctul de plecare înspre conceptul juridic de bună-credință, aşa cum va fi înțeles de-a lungul veacurilor. Trecerea de la fides la bona fides poate fi interpretată ca o fațetă a perpetuei încercări de a defini comportamente și de a transpune în teorie unele reguli. Acest proces a durat mulți ani, anumite transformări fiind necesare datorită expansiunii romane și înmulțirii relațiilor comerciale ${ }^{30}$. Cicero, după ce definește buna-credință ca fiind sinceritate în cuvinte (veritas) și fidelitate (constantia) în angajamente ${ }^{31}$, în cartea a treia din De officiis oferă multe exemple în acest sens, standardele etice și legale fiind noțiuni al căror conținut fluctuează în funcție de condițiile

${ }^{26}$ D.H. van ZYL, op.cit. Pentru detalii referitoare la contractele de drept strict se vedea M.D. Bов, op.cit., p. 193.

27 Ibidem. M.D. BoB, op.cit., p. 308.

${ }^{28}$ Aici putem aminti și expresia bonus vir, care presupune un comportament onest față de ceilalți oameni. În timp, bona fides și bonus vir au ajuns să nu poată fi folosite separat.

29 P. Catalano, Ordinario di Diritto Romano nell'Universita di Roma, La Sapienza, Diritto e Persone, vol.I, G. Giappichelli Editore, Torino, 1990, p. 9 apud V.M. CIUCĂ, op.cit.

$3^{\circ}$ M. Jovanovic, Aequitas and bona fides in the legal practice of Ancient Rome and the prohibition of the abuse of rights, Facta Universitas, vol.1, nr.7, 2003, p. 766.

${ }^{31}$ CICERO, De officiis, 1.7. 
sociale în care pot fi aplicate ${ }^{32}$. Fiind un fin observator al substratului moral al noțiunii de bona fides filozoful amintit menționează că:

„Semper autem in fide, quid seseris non quid dixeris cogitamdum." 33

\section{OPERTERE EX FIDE BONA}

În domeniul bunei-credințe este esenţial să evocăm şi instituţia pretorului, care a jucat un rol important în dezvoltarea Dreptului Roman. Acest magistrat este cel datorită căruia inflexibilul ius civile a devenit mai suplu, prin găsirea de remedii acolo unde dreptul civil nu le deținea. Soluțiile sale inovatoare erau înscrise în edictul pretorian, care împreună cu cele ale predecesorilor formau ius praetorium ${ }^{34}$.

De asemenea, romanii vor da acestei sintagme un caracter procesual, anume o caliate a unor acțiuni care în intentio a formulei se structurau oportere ex fide bona ${ }^{35}$. Așadar, conceptul de bună-credință a fost, pentru romani, motivul și temelia creării unei noi categorii de acțiuni, bonae fidei iudicia $^{6}$. La geneza acestei acțiuni au stat raporturile comerciale cu peregrinii, însă rolul acestora nu trebuie să fie exagerat: dacă locatio conductio (care a luat naștere datorită relațiilor de comerț) va fi sancționat prin bonae fidei iudicia, contractul de mandat, de exemplu, sancţionat tot

$3^{2}$ D. NORR, op.cit., p. 309.

33 CiCERO, De officiis, 1.13.

34 D.H. VAN ZYL, op.cit., p.95. Ius praetorium a fost o componentă a ius honorarium al magistraților romani care dețineau ius edicendi.

35 J.H. FAcco, Oportere ex Fide Bona. Una Construccion Decisiva de la Jurisprudencia Romana, 24 Rev. Derecho Privado, 2013, p.17.

${ }^{36}$ D. NORR, op.cit., p. 307. 
printr-o acțiune de bună-credință, nu le datorează apariția37. Sub atenta supraveghere a pretorilor, majoritatea problemelor juridice și-au găsit rezolvarea în forma actiones utiles și a aciones in factum.

Apariția acestui tip de acțiuni a fost o reformă procedurală ${ }^{38}$. In materie de procedură, buna-credință se manifestă prin puterea acordată judecătorului (officium iudicis) de a aprecia faptele aduse spre soluționare. Astfel, actio bona fidei sunt: actio tutelae 39 , actio pro socio, actio fiduciae, actio ex empto, actio venditi, actio conducti, actio locati. În aceste situații, iudex-ul avea posibilitatea să realizeze o investigație completă și detaliată a circumstanțelor speței referitor la:

- comportamentul părților în vederea realizării obligației.

- apariția unu caz de dol, de vis sau a altor situații similare aferente contractului care puteau da naştere utilizării excepțiilor de procedură, fără ca anterior cocontractanții să fi încheiat vreo înțelegere în acest sens ${ }^{40}$.

- aplicarea compensației ${ }^{41}$.

- pacta conventa dintre părți, care funcţionau ca leges privates ce trebuiau respectate. În consecință, pacta adiecta la contractul principal erau considerate ca făcând parte din acesta, chiar dacă au apărut pe parcursul realizării obligației. Astfel, îndeplinirea acestor

37 C. C. TURPIN, op.cit., p. 264.

${ }^{38}$ F. WiEACKer, Zum Ursprung der Bonae Fidei Iudicia, ZSS,80, 1963, p. 12 apud C. C. Turpin, op.cit., p. 264-264.

39 Se pare că este singura acțiune de bună-credință care poate fi încadrată, cu certitudine, temporal: consulul Quintus Mucius SCAEvola aminteşte despre ea în anul 95 î.Hr. A se vedea şi CICERO, De officiis, 3.17.70.

40 J.H. FACCO, op.cit., p.27.

${ }^{41}$ M. TalamanCA, Processo civile dirrito romano, p.65 apud J.H. FACCO, op.cit., p.29.

\section{8}


pacte putea fi cerută prin acțiunea ce deriva din contractul inițial, fără apelarea la nicio excepție, deoarece: in bonae fidei iudicio esceptiones pacti insunt ${ }^{42}$.

- determinarea valorii prejudiciului invocat de către reclamant, sub forma de interese moratorii sau compensatorii43. Jurisconsulții clasici au individualizat încă de la finele Republicii această categorie de acțiuni ca fiind cu intentio incerta44. În acest mod au fost soluționate diferende care aveau ca obiect nu numai sume de bani sau bunuri determinate, ci și orice obligație de a da, a face sau a nu face45. Se pare că datorită acestei practici, judecătorului i s-a oferit aceeaşi libertate și în situația acțiunilor de drept strict, dar în care nu era certă valoarea pagubei ${ }^{46}$.

„Formula care îi prescria judecătorului să cerceteze ceea ce datorează ex fide bona îi dă o nouă putere, în virtutea căreia afacerile devin mai facile în consecințele lor”, susține Paul Federic Girard47.

Dacă acțiunea introdusă nu conținea cuvintele bona fides, judecătorul nu verifica toate aceste detaliii ${ }^{48}$.

În raporturile juridice bazate pe bona fidei iudicia fiecare parte contractuală trebuie să acționeze, față de cealaltă, cu loialitate. Tratând acest caracter reciproc al relațiilor de bună-credință, doctrina clasică a dezvoltat

\footnotetext{
42 A. D’Ors, Derecho Privado Romano, p. 510 apud J.H. FACCO, op.cit., p.30.

43 M. TALAMANCA, op.cit., p.65 apud Javier Humberto FACCO, op.cit., p.31.

44 J.H. FACCO, op.cit., p.21.

45 Idem, p.24.

46 C.C. TURPIN, op.cit., p. 267.

47 P.F. GIRARD, Manuel elementaire de droit romain, Paris, 1911, p. 439 apud D. Gherasim, op.cit., p. 41.

${ }^{48}$ L. WAELKENS, op.cit., p. 6.
} 
conceptul de culpa. Ulterior, autorii postclasici au operat cu categorii diverse de cuplă, în funcție de speța întâlnită49.

După cum am amintit, la origini, fides bona a fost un concept moral (forum internum ${ }^{5}$ ) suficient de flexibil pentru a cuprinde toate tipurile de proceduri juridice utilizate în procedura formulară. Acest concept a fost creat și modelat de experiența juridică pentru un obiectiv specific: de a fi implementat în acea lume procedurală care pentru universul juridic roman constituia un ghimpe ${ }^{5}$.

Totuşi de ce practica procesuală a recurs la bona fides atâta timp cât simplul fides avea deja o semnificație morală pozitivă? Se pare că răspunsul este unul simplu: era nevoie de un criteriu tipizat care să depășească o apreciere strict individuală și care să permită rezolvarea contradicțiilor apărute între posibilele interpretări date lui fides. Simpla fides presupune o apreciere subiectivă, individuală. Din contră, bonum este un criteriu care îi implică pe toți, adică o valoare supraindividuală, obiectivă, care conferă generalitate, evocând o normă depersonalizată cu caracter absolut. Acest fapt explică de ce termenul de bona fides se folosea inter-individual, desemnând credința față de un om, nu față de un pact52. Un alt atribut al conceptului de fides îl constituie polivalența: are caracter oficial, social şi religios. De exemplu este folosit fides, iar nu bona fides, ca şi criteriu atunci când se stabilește infamia53. Observăm aşadar că principiile care presupun

49 A. DI PIETRo, Los negotios patrimoniales y los contratos en el derecho romano, Buenos Aires, Abaco, 1998, p.180 apud J.H. FACCO, op.cit., p.30-31.

50 V.M. CIUCĂ, Bona fides într-o nouă hermeneutică, 2015, https://juridice.ro/essentials/246/bona-fides-intr-o-noua-hermeneutica.

${ }^{51}$ R.M. RAMPELBERG, op. cit, p. 58.

$5^{2}$ P. ARIES, G. DubY, op.cit., p. 180.

53 L. LOMBARDI, op. cit., p. 178 apud R.M. RAMPELBERG, op. cit. 
responsabilitatea cuiva se fondau pe fides. Per a contrario, polivalenței lui fides i se opune uniformitatea formulei ex fide bona. Aceasta ne duce la ideea că bona fides ar fi avut o funcțiune diferită de cea a lui fides. În comparație cu vasta categorie socială şi morală reprezentată de fides, bona fides apare ca o specie individualizată într-un gen mult mai larg54.

Un principiu important, în caracterizarea bunei-credințe ca termen juridic, îl reprezintă bona fides praesumitur 55 . Datorită acestei caracteristici, ea este considerată de către specialiști un antidot pentru fenomenul de inflație legislativă și de formalism juridic ${ }^{6}$ existente în Roma republicană.

După cum am observat, bona fides nu este un concept exclusiv etic; vorbim aici despre o inovație cu conotaţii morale certe, strâns legată de evoluția juridică a societății romane. Cu toate acestea, dorim să accentuăm faptul că bona fides nu este un concept care să fi stat la temelia constituirii sistemului juridic roman sau a ordinii sociale57. Bazele moral-filozofice utilizate de către jurisconsulții romani sunt cele care au stat la baza dezvoltării mecanismelor juridice de mai târziư58:

„Iuris praecepta sunt haec: honeste vivere, alterum non laedere, suum cuinque tribuere."59

Tot de la Cicero aflăm răspunsul la modalitatea în care romanii au reuşit să pună în practică definiția de mai sus. În acest sens, el îl amintește pe Quintus Scaevola, pontifex maximus, care a mărturisit că formula ex fide

54 L. LOMBARDI, op. cit., p. 180 apud ibidem.

55 Buna-credință se prezumă.

$5^{6}$ V.M. CIUCĂ, op.cit.

57 Dictionnaire de la culture juridique, p. 143.

58 P. J. Thomas, Bona fides, Roman Values and Legal Science, 10 Fundamina, 2004, p.190. 59 UlPIAN, D. 11.10. 
bona are un conținut juridic foarte puternic și că această expresie prezintă o largă aplicabilitate în toate chestiunile sociale: tutelă, fiducie, mandat, cumpărare, vânzare, închiriere, angajare, asociere ${ }^{60}$. Ele conțineau o clauză de dol, subînțeleasă, care prevedea că:

„Pacta conventa quae neque dolo malo, neque adversus leges, plebiscita, senatusconsulta, edicta, decreta princium, neque fraus cui eorum fiat, facta erunt servabo."61

Ca exemplu practic, într-o scrisoare expediată lui Atticus în anul 50 î.Hr., Cicero îl informează pe acesta că a introdus în edictul său o clauză care are aceeași forță juridică cu cea din edictul lui Quintus Mucius Scaevola, „cu condiția ca fapta supusă judecății să fie de așa natură încât să nu intre în conflict cu buna-credință"62.

Prin intervenția pretorului, buna-credință devine o condiție esențială pentru validitatea consimțământului în cadrul raporturilor juridice obligaționale ${ }^{63}$; aceasta nu înainte ca fides să guverneze relațiile nerecunoscute de dreptul civil, însă în care părțile își dăduseră acordul ${ }^{64}$, după cum am amintit. Unii cercetători susțin că nu era necesară invocarea expresă a lui fides ca anumite contracte (vânzare, închiriere) să își producă efectele; ca argument ne sunt prezentate actio Serviana și actio Publiciana în care bona fides și ocolirea dolului sunt bazele morale, însă în care nu se

\footnotetext{
60 CiCERO, De officiis, 3.17.

${ }^{61}$ Fr. GoRPHE, Le principe de la bonne foi, Dalloz, Paris, 1928, p. 14 apud D. GHERASIM, op.cit., p. 41.

62 D.H. vAN ZYL, op.cit., p. 97.

63 V.M. CIUCĂ, op.cit.

64 C.C. TURPIN, op.cit.
} 
face referire la fides ${ }^{65}$. Opertere ex fide bona este o construcție jurisprudențială romană care își are rădăcinile în sec. III-II î.Hr., probabil înainte de emiterea lex Aebutia ${ }^{66}$. Prin bona fides s-a realizat transpoziția lui verbum (obligație contractată între cetățeni romani în cadrul legis actiones) pe scena noilor contracte comerciale ${ }^{67}$. În ciuda implementării sale de tip pretorian, clauza quidquid dare facere oportet ex fide bona a reprezentat o elaborare cu caracter jurisprudențial venită din gândirea jurisconsulților romani ${ }^{68}$. Dacă legis actio in personam presupunea rostirea sintagmei aio te mihi dare oportere, în procedura formulară se utiliza quidquid... dare facere oportet ex fide bona ${ }^{69}$. Bona fides era invocată în formulă (în intentio), nu ca sursă de obligație, ci cu scopul de a atribui judecătorului libertate în emiterea sentinței.

Istoric vorbind, acțiunile de bună-credință își au originea în iudicia honoraria, fundamentându-se pe imperium-ul magistraților ${ }^{70}$. Dreptul clasic a transformat bonae fidei iudicia în iudicia legitima ${ }^{71}$. Considerăm că această modificare a survenit nu numai datorită obligativității judecării tuturor cauzelor în fața unui iudex unus, ci și vechimii considerabile a conceptului de fides, prezenței lui în formula de oportere - termen asociat cu dreptul civil al obligațiilor. În acest mod au facilitat preluarea acțiunilor de bună-credință în cadrul instituțiilor de ius civile. Această receptare, conform romaniștilor, ar fi

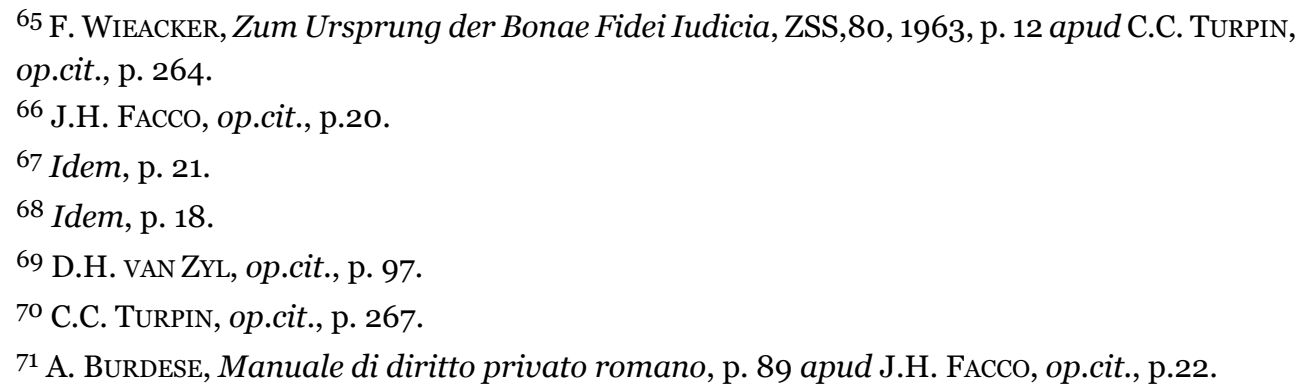


avut loc în ultima parte a Republicii ${ }^{2}$. În dreptul clasic, intentiones a tuturor bonae fidei iudicia au fost încadrate ca in ius conceptae ${ }^{73}$.

\section{BONA FIDES ÎN CONTRACTE}

După cum am amintit, fides obliga părțile să își țină promisiunea făcută, iar comporatamentul lor să fie conform acesteia. Câteva exemple în acest sens:

„Item, in his contractibus alter alteri obligatur de eo quod alterum alteri ex bono et aequo praestare oportet."74

Similar, Tryphoninus:

„Bona fides que in contractibus exigitur aequitatem summam desiderat." 75

În continuare, vom detalia câteva situații care atestă aplicabilitatea principiului bunei-credințe în Dreptul Roman.

În cazul contractului de vânzare, vânzătorul poate fi considerat responsabil pentru dolus, sintagma bonae fidei iudicia având în această materie aplicabilitate preponderentă ${ }^{76}$. Explicația rezidă din faptul că fides bona se află în antiteză cu dolus malus: „Vânzătorul este vinovat numai pentru dolus deoarece ex empto este o bonae fidei iudicium și bona fides este opusul lui dolus."77 Acest antipod terminologic se întâlnește în multe din

\footnotetext{
72 A. Magdelain, Les Actions Civiles, p.54 apud C.C. Turpin, op.cit., p. 268.

73 C.C. TURPIN, op.cit.

74 GaIUs 3.137.

75 TRYPHONINUS, D. 16.3.31.

${ }^{76}$ A. RuIz, Instituzioni (2), p. 350 apud W. W. BuckLAND, Culpa and Bona Fides in the Actio Ex Empto, 48 L. Q. Rev. 217 (1932), p. 226.

77 Idem, p. 227.
} 
textele jurisconsulților, atât actio doli, cât și actio metus fiind frecvent întâlnite în cuprinsul formulei ${ }^{78}$. Astfel,

„(...) quia fides bona contraria est fraudi et dolo."79

De asemenea,

„(...) nihil consensui tam contrariam est, qui ac bonae fidei iudicia sustinet, quam vis et metus." ${ }^{80}$

Așadar, evocarea bunei-credințe va deveni importantă pentru cocontractanți nu doar în ceea ce privește simpla prestație asumată, însă și în ceea ce privește realizarea ei într-o manieră care nu implică dolul, ci se conjugă criteriilor de loialitate şi onestitate ${ }^{81}$. Anterior acti doli, pretorul a creat exceptio doli, un mijloc procedural de protecție a pârâtului în situația în care fusese învinuit pe nedrept ${ }^{82}$.

Totodată, bona fides îl obligă pe vânzător să indice cumpăătorului limitele proprietății vândute ${ }^{83}$, însă este în contradicție cu buna-credință ca depozitarul să fie ținut răspunzător pentru ceva, înainte de a săvârşi fapte din categoria mora $^{84}$. Noțiunea de bona fides a fost utilizată inclusiv în domeniul dobândirii fructelor şi a dobânzilor ${ }^{85}$. În bonae fidei iudicia, liberum est

78 F. SchulZ, Classical Roman Law, 1951, p. 600-602 apud D.H. van ZYL, op.cit.

79 PAUl, D.17.2.3.3: „nimic din ce este dolo nu poate fi bona fide.”

80 ULPIAN, D.50.17.116.pr: nimic nu se opune atât de mult consimțământului, care este baza acțiunilor de bună-credință, ca violența și frica.

${ }^{81}$ J.H. FACCO, op.cit., p.39.

82 L. WINKEL, Forms of imposed protection în legal history, especially in Roman Law, in Erasmus Law Review, vol. 3, 2010, p. 156.

83 SCAEVOLA, D.19.1.48.

84 PAPINIAN, D.16.3.24.

85 UlPIAN, D.16.3.1.23, 24; 44.2.23. PAUL, D.18.4.21; 22.1.38; MARCIAN, D.22.1.32.2. 
officium iudicis ${ }^{86}$, astfel că el se poate folosi sau nu de drepul la compensatio, după cum consideră de cuviință.

„Placuit enim prudentioribus affectus rationem in bonae fidei iudiciis haberi." 87

„Generaliter observari convenit bonae fidei iudicium non recipere praestationem quae contra bonos mores desideratur." 88

În materie de tutelă un tutore are posibilitatea, cum bonae fidei iudicium sit, să cheltuie din averea pupilei pentru a le întreține pe mama şi pe sora acesteia ${ }^{89}$.

De asemenea, actio mandati conține clauza de bună-credință, așa cum este descrisă de Gaius:

„(...) et invicem alter alteri tenebimur in id, quod vel me tibi vel te mihi bina fide praestare oprtet. "9o

Totodată, bona fides s-a folosit ca remediu procedural și în cazul contractelor de depozit şi de comodat91, dar și când speța pornea de la un pignus $^{92}$. Aceste trei tipuri de iudicia bonae fidei au fost introduse de pretor în perioada Dreptului Roman clasic, aşa cum susține Laurens Winkel93.

În raporturile contractuale, buna-credință nu permite o plată dublă pentru aceeași prestație (bona fides non partitur ut bis idem exigatur ${ }^{94}$ ).

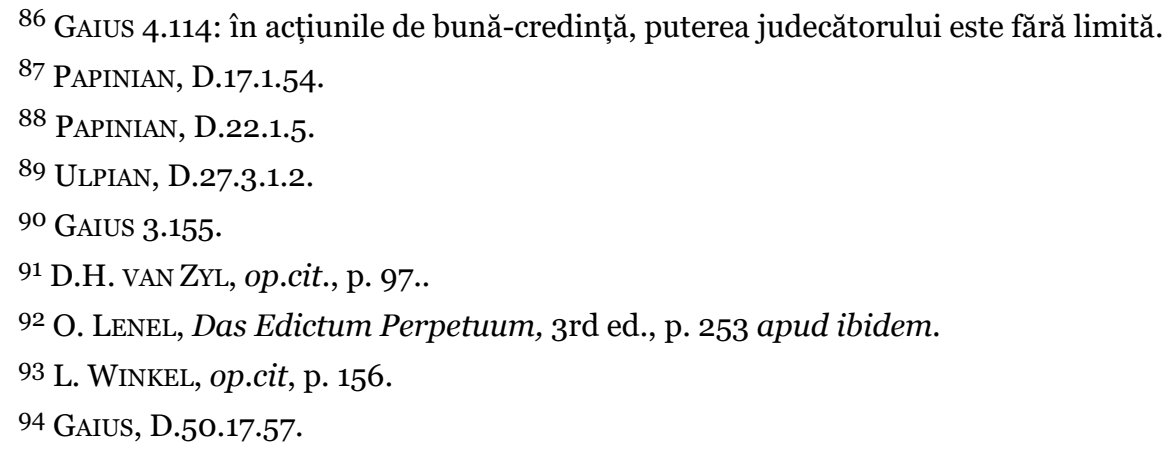


Buna-credință, fiind convingerea sinceră a celui care crede că un bun îi aparține (bona fides est illaessa putantis rem suam esse), o întâlnim şi în materie de posesie.

\section{BONA FIDES ȘI AEQUITAS}

Un concept apropiat celui de bun-credință a fost aequitas, cercetători ca Alan Watson considerând că noțiunile aequum, aequum bonum și bona fides sunt identice95. Cu toate acestea, conform lui Fritz Pringsheim ${ }^{96}$, s-au înregistrat anumite diferențe între iudicia bonae fidei și actiones in bonum et aequum conceptae:

- bona fides aparține de ius civile, în timp ce aequitas este un instrument pretorian;

- bona fides reprezintă un aspect central al dreptului roman, pe când aequitas deține un rol periferic;

- iudex-ul decide conform limitelor și efectelor bunei-credințe în timpul fazei in iudicio, pretorul luând decizia pe baza echității în faza in iure a procesului;

- bona fides are caracter procedural, în timp ce aequitas are legătură cu soluția oferită de pretor unor procese viitoare;

- bona fides reprezintă manifestarea concretă a unei persoane, iar aequitas este un criteriu abstract, general prin care se stabilesc principii legale.

\footnotetext{
95 A. WATson, Law making in the later Roman Republic, 1974, p. 176 apud D.H. VAN ZYL, op.cit., p. 102.

$9^{6}$ F. Pringsheim, Aequitas und Bona fides, in Pringsheim Gesammelte Abhandlungen, 1, p. 156-173 apud D.H. VAN ZYL, op.cit. p. 103-104.
} 
În ciuda acestor diferențe, cele două concepte au devenit atât de unite, încât în dreptul post-clasic vor ajunge să fie folosite una în locul alteia97. Prin urmare „acțiunea de bună-credință prezintă ideea de echitate”98. Chiar împăratul Dioclețian sugerează că este echitabil ca buna-credință să apară în contracte 99 .

\section{CONCLUZII}

În timp, non consentiunt qui errant devine un principiu al Digestelor lui Iustinian. Se poate totuși concluziona că prin codificarea împăratului s-a oferit suficientă libertate judecătorilor pentru a acționa conform principiului bunei-credințe? Răspunsul afirmativ îl primim analizând textele jurisconsulților citați în Corpus Iuris Civilis, multe dintre ele făcând referire la justiție, caracterul just, egalitate, conștiință și dreptate ${ }^{100}$. Cu toate acestea, în anumite circumstanțe, Iustinian a limitat strict rolul judecătorilor, impunându-le să adere la soluțiile existente în Codex, Digeste, Instituții, respectiv Novele ${ }^{101}$.

Alături de schimbările menționate mai sus, majoritatea datorită practicii, aplicarea principiului bunei-credințe va determina şi diminuarea abuzului de drept existent în societatea romană ${ }^{102}$. Așa cum Gaius indică:

97F. PRINGSHEIM, op. cit., p.161 apud D.H. vAN ZYL, op. cit., p. 104.

$9^{8}$ A. H. J. GreEnIDGE, The Legal Procedure of Cicero's Time, 1901, p. 202 apud DH VAN ZYL, op.cit., p. 104.

99 C. 4.10 .4 .

100 M. JovANOVIC, op.cit., p. 764.

${ }^{101}$ Ibidem.

102 Ibidem. 


\section{„Male enim nostro iure uti non debemus."}

Putem concluziona că buna-credință, în vechiul drept roman, a servit ca fundament al acordurilor comerciale neformale între cetățenii romani și peregrini. Ulterior, acest principiu a ajuns să îmbogățească conținutul raporturilor obligaționale născute din contracte, prin asumarea de către părți a unui comportament conform unui bonus vir ${ }^{104}$. Întâlnim sintagma bona fides în cele mai vechi surse de drept civil clasic, ca Edictul Perpetuu şi Instituțiile lui Gaius, și o găsim aplicată inclusiv în dreptul imperial, dovadă fiind Corpus iuris. Va fi studiată în facultăţile erei medievale şi va primi un loc de cinste în dreptul civil occidental ${ }^{105}$. Probitatea, diligența, liceitatea și abținerea de la vătămarea sau păgubirea altuia (alterum non laedere) ca elemente componente ale bona fides, au tradus, în plan juridic, acel honeste et recte vivere preluat de la stoici ${ }^{106}$. În prezent, multe dintre mijloacele de protejare a părții vătămate dintr-un raport contractual sunt văzute ca extensii ale vechiului criteriu roman al bunei-credințe ${ }^{107}$.

Prin această scurtă prezentare considerăm că am pus în lumină evoluția de la caracterul etico-religios la cel strict juridic a unui concept important pentru dreptul roman. Bona fides este acea prezumție care a învins ultimele rămășițe ale ritualismului protorepublican în epoca clasică romană ${ }^{108}$. În încheiere subliniem faptul că valorile pe care s-a clădit dreptul

103 GAIUS 1.53 .

104 R. CARDILLI, Bona fides tra storia e sistema, p. 101 apud J.H. FACCO, op.cit., p.41.

105 L. WAELKENS, op.cit., p. 2.

${ }^{106}$ D. GHERASIM, op.cit., p. 8-10.

107 L. WINKEL, op.cit., p. 162.

108 A. Schiavone, Sulle dottrine contrattualistiche dei giuristi romani, Index. Quanderi camerti di studi romanistici. Nel nome di Giorgio la Pira, Jovene Editore Napoli, 23/1995, p. 536 apud V.M. CIUCĂ, op.cit. 
roman și instrumentele juridice dezvoltate de către jurisconsulții Romei rămân astăzi la fel de importante cum s-au dovedit a fi de-a lungul istoriei dreptului în cultura europeană. 